\title{
Process of Strategic Management at Surabaya City Government in Achieving Green City Master Plan (GCMP)
}

\author{
Bayu Rizky Aditya ${ }^{\text {* }}$ \\ ${ }^{a}$ Universitas Brawijaya, Malang, Jawa Timur, Indonesia
}

\section{INFORMASI ARTIKEL}

\section{Article history:}

Dikirim tanggal: 01 Februari 2016

Revisi pertama tanggal: 22 Maret 2016

Diterima tanggal: 31 Mei 2016

Tersedia online tanggal 10 Juni 2016

Keywords: strategic management, publicmanagement, environmental management, people participation, green city

\section{ABSTRACT}

This study aims to show the strategic management process of Surabaya City Government in achieving Green City Master Plan (GCMP), especially from the beginning to the end of process. This study analyzed the strategic management process of Surabaya City Government by using qualitative research with an interview to key informants in Surabaya Development Planning Board and analyze Surabaya Development Planning Documents. The result showed that the process is conducted through environmental scanning, formulation, implementation, control and evaluation process which is carried out continuously. The utilization of IT and social media as a liaison between the government and society, allowed the government to create an appropriate program which is supported by the society. The process that has been passed by Surabaya City Government is supposed to be a pilot project for other similar areas to be more effective in achievement of GCMP.

\section{INTISARI}

Penelitian ini bertujuan untuk menunjukkan bagaimana proses managemen strategis oleh Pemerintah Kota Surabaya dalam mencapai Rencana Induk Kota Hijau (RIKH), terutama dari awal hingga akhir proses. Penelitian ini menganalisis proses managemen strategis oleh Pemerintah Kota Surabaya dengan menggunakan penelitian kualitatif dengan melakukan interview kepada aktor kunci yang berada di Badan Perencanaan Pembangunan Kota Surabaya serta menganalisis dokumen perencanaan pembangunan Kota Surabaya. Hasil penelitian menunjukkan bahwa proses managemen stratgis dilakukan melalui proses analisis lingkungan, formulasi, implementasi, kontrol dan evaluasi yang dilakukan secara berkelanjutan. Penggunan IT dan sosial media sebagai penghubung antara pemerintah dan masyarakat menjadikan pemerintah dapat menciptakan sebuah program yang tepat yang juga didukung oleh masyarakat. Proses yang telah dilalui oleh Pemerintah Kota Surabaya seharusnya menjadi sebuah pilot project bagi daerah lain yang serupa, agar lebih efektif dalam dalam pencapaian $(\mathrm{RIKH})$ 


\section{Introduction}

The increasing of Indonesian development activities is potentially contain the risk of pollution, environmental damage, climate change and environmental degradation. This condition can become a social burden and threat to the survival of human life. All of this can be happen if there is no good planning. While the Indonesian Constitution stated that good and healthy environment is a fundamental right for every Indonesian citizen (Indonesian Act number 32, 2009). Therefore, state, government, and all of the stakeholders are required to take responsibility of environmental protection and management properly based on the principle of state responsibility, justice, environmentally friendly, and sustainable development. Environmentally, sustainable development will increase durability to any changes in the environment (Wikantiyoso \& Tutuko, 2013). Environmental management must be able to provide the benefit of economy, social, and culture that is based on the precautionary principle, environmental democracy, decentralization, recognition and respect for local and environmental wisdom, so that the environment can remain a source of life and support for the Indonesian people and other living creatures.

Environmental protection and management requires an integrated system in the form of a national policy of environmental protection and management that should be implemented in strict principles and consequences from the center to the local government. In order to ensure legal certainty and provide protection of human right to obtain a good living and healthy environment as part of the overall ecosystem, then the government formed an Act number 32 of 2009 about environmental protection and management.

The Act number 32 of 2009 provides broad authority to the cabinet to carry out all government activities in the field of environmental protection and management as well as coordination with other agencies. Through this act, the government also gives empower the local government in protecting and managing the environment in its respective areas based on the principles of local government. It means that the local government regulates and manages its own affairs in the field of environmental protection and management by paying attention to the specificity and diversity of the regions. It is also in accordance with the mandate of Indonesian Constitution of 1945, which stated that "the local government has the authority to regulates and manages its own affairs in accordance with the principle of autonomy and co-administrative." It is also similar to Indonesian Act number 32 (2004) which staed that "the granting autonomy to the region is directed to accelerate the realization of public welfare through service improvement, empowerment and community participation."

The local government is required to be more responsive to the changes of environmental conditions and adjusts its services and function to the Act number 32 of 2009. Backoff et al (1993) argue that constitutional or charter designs significantly affect the strategic management of the agencies of general purpose local government. Therefore, the Act number 32 of 2009 about environmental protection and management also affects the strategic management of local government accordingly. As proposed by Kloot and Martin (2000), there should be a strong linkage between strategic plans and performance. It means, local government performance in environmental protection and management is interrelated to its strategic management.

The local government is adopts and uses strategic management methods developed by the private sector to address and solve its problems (Ring \& Perry, 1985). Strategic management applied in each region helps adjust and accelerate the achievement of government goal especially in environmental management and protection. Many of local governments are successful and Surabaya City is one of them.

Since the era of Dutch East Colony in Indonesia, Surabaya City has become the largest city and the busiest port in early $20^{\text {th }}$ century. By utilize Sungai Brantas (Brantas River), which stretches from Batu City and end in Mojokerto City, has gave an impact to the development of Surabaya. The birth of modern economic institution also give an impact to the increasing of economic activities in Surabaya. Then, Surabaya has been growing and equal to the famous trading port cities in Asia, such as Singapore, Bangkok, Hong Kong and etc. From all of this, Surabaya makes more newcomers from outside Surabaya to life and start a new business in the city.

Pollution of water, air and soil are environmental problems that cannot be avoided by the city of Surabaya as the impact of various activities of the metropolis is increasing. According to Environmental Board of Surabaya City Government (2009), since 2001, the city of Surabaya suffered contamination to the clean water and river water as a result of business activities that result waste water to the drainage channel and the river water bodies. Surabaya river water conditions not meet the water quality standards in Government Regulation No. 82 of 2001 and the Surabaya City Regulation No. 2 of 2004 on the Management of Water Quality and Water Pollution Control. A decrease in air quality due to vehicle exhaust emissions and stack emissions from industrial activities, and soil pollution due to low public awareness in environmental preservation, especially sanitation problems. 
Environmental problem in Surabaya City is also described by Sutawijaya (2010:1-2) that in October 2001, almost one and a half months garbage in the city of Surabaya is not transported to Keputih landfills because of the refusal of communities around the landfill caused by the presence of landfill, then resulted in very poor environmental conditions: stale air from burning garbage, contaminated with leachate, a foul smell is also very disturbing. From the problems that emerged above, it appears that the environmental policy created by Surabaya City Government has not run maximally.

The environmental problem which occurs in Surabaya City indicates that the process of policy formulation to control and evaluation does not run optimally. Policies that have been created at that time cannot be implemented effectively. It showed that there is a mismatch in the policy formulation so that the implementation process was failed.

In the new era of Tri Rismaharini, Surabaya City Government committed in preserving its environment and make it into a green city. In order to realize the Vision of Surabaya City as the "City of Service and Smart Trade, Humanized, Dignified and Environmental Perspective", Surabaya City Government create GCMP. GCMP consist of 8 aspects, namely: Green Planning and Design, Green Transportation, Green Waste, Green Space, Green Community, Green Building, Green Water and Green Energy (DPUCKTR, 2013). Green city concept was conceived as an answer that emphasizes aspects of environmental sustainability considerations in solving the urban problems (Murota and Ito, 1996).

By using GCMP, Surabaya City Government (2015) has been directing the city with various excellent projects to be the leader in preserving a good environment. It can be seen from some national and international awards from 2006 received by Surabaya City related to the environmental preservation. In 2013, Surabaya City awarded as the first rank of cleanest city with Adipura Kencana ${ }^{1}$ (Sani, 2013). The achievement of Surabaya City Government in environmental protection and management in accordance with Çınar \& Karcioğlu (2013) which argue that an organization will survive for a long time if it managed professionally with strategic management.

According to Indonesian Constitution of 1945, every citizen has rights to obtain a good living and healthy envinronment. Thus, a decent environment for the citizen become one of the objectives for local government to be achieved.

1 Adipura Kencana is an award given to the cities that meets environmental management performance beyond compliance.
According to Nuh (2014), "each local government in Indonesia has used strategic management to support governance and the development of master plan in short and long term." It means that local government used strategic management to achieve local government objectives such as a decent environment. It also accordance with what was agreed by some scholars that strategic management is an ongoing process to achieve the objectives. (David, 2007; Dess et al, 2010; Gecíková \& Papcunová, 2014; Wheelen et al, 2015).

However, it contradict with the fact that occur in Indonesia. There are still local governments which has not yet reached a standard of decent environment as their objective. It can be seen from Adipura Rated and Ranked of 2013, which show that from 374 cities in Indonesia, there are 2 metropolitan cities, 5 big cities, 17 medium cities, and 139 cities that score below 7 (Sani, 2013). This indicates that there is something wrong in their strategic management process or the steps of environmental scanning, strategy formulation, strategy implementation, or evaluation and control is not done well. So the efforts to achieve the objective did not go well.

Furthermore, this study want to show that the strategic management model which is used and developed by Surabaya City Government might be one of the most effective model to be used by another local government to become more effective in managing a green city. It can be used as the concept for other regions to adopt and adjust the strategic management process in accordance with the characteristics of each regions and also accelerate the development of other regions to be more effective and efficient to achieve the objective. As describe by Lynn (2006:1) that a vital success in government programs and policies is done by an effective management. It is like the notion from David Jaquith which said "Good result without good planning comes from good luck, not good management" (Bainey, 2004:164). Therefore, in this research, the researcher wants to study about the strategic management process of Surabaya City Government in achieving GCMP, especially from the beginning of preparation to the evaluation and control process. This study has two contributions of both practical and theoretical.

\section{Theory}

The utilization of strategy is not only used by the business, it also used in public or private organization, formal and informal organization (Levicki, 1999). Strategy is made by at least one strategist who got the responsibility for the successful formulation and implementation (White, 2004). Nowadays, public sector organizations are facing a market dynamic problems, such as advances technology, global economy, an 
increase of social demands and the need of an effective way in providing a social services with limited resources. (Nutt \& Backoff, 1993; Mclnerney \& Barrows, 2002). To the continued viability and effectiveness of governments, the public sector transfer private sector concepts, such as strategic management (Bryson, 1998; Gecíková \& Papcunová 2014).

Strategic management includes scanning in both of internal and external (environmental scanning), strategy in formulation such as medium or long-range planning, strategy in implementation, and control and evaluation (David, 2007; Dess et al, 2010; Gecíková \& Papcunová, 2014; Wheelen et al, 2015). A vital success in government programs and policies is come by an effective management (Lynn, 2006:1). Strategy is one of strategic management tool used in local government to address issues related to the quality of life of local people (Gecíková \& Papcunová, 2014).

Bryson (1998) argued that a strategic thought and action are become an important way for the sustainable life and effectiveness in public sector such as governments, public agencies and all of non profit organizations. He also added that the using of strategic planning is an important part and some of these organizations will be able to meet successfully the numerous challenges that face them. According to Gecíková \& Papcunová (2014) strategy is one of strategic management tool used in local government to address issues related to the quality of life of local people. And the decisions are usually general and longterm.

Green city concept is one of the answer to solving environmental problem. It stressed on how to solve global warming and urban problems, as it also created an environmental sustainability (Wikantiyoso \& Tutuko, 2013; Murota \& Ito, 1996). It arrange urban space to put green space as an assets, potential, and long-term investment of city to has economic values, ecological, educational, and aesthetic as an important part of the city (Widigdo \& Canadarma, 2010). The main objectives of green city concept is a sustainable development.

With green city concept, the city is providing green area for healthy lifestyles such as, bicycle route, pedestrian area, physical exercise, opportunities to socialize, connections to place and nature, enjoyment and fun, (Beatley, 2012; Brüel, 2012). There are 8 elements of green city, there are focus on energy; planning \& design; open space; building; transportation; water; waste, community (Aditya, 2016).

\section{Research Method}

This study use qualitative method and provide a clear description about the strategic management process of Surabaya City in achieving GCMP. The focuses in this study are:

a. How is the environmental scanning in strategic management process of Surabaya City Government to achieve Surabaya GCMP, the researcher focus on external and internal environment, namely:

1) External: Opportunities and Threats;

2) Internal: Strengths and Weaknesses.

b. How is the strategy formulation in strategic management process of Surabaya City Government to achieve Surabaya GCMP, the researcher focus on 4 aspects, namely:

1) Mission;

2) Objectives;

3) Strategies;

4) Policies.

c. How is the strategy implementation in strategic management process of Surabaya City Government to achieve Surabaya GCMP, the researcher focus on 3 aspects, namely:

1) Programs;

2) Budgets;

d. How is the control and evaluation in strategic management process of Surabaya City Government to achieve Surabaya GCMP, the researcher focus on performance aspects.

The data were obtained through an interview with three key informants in Development Planning Board (next called as BAPPEKO), Surabaya City Government. They were Head of General and Staffing; Head of Environment and Spatial Affairs; and Head of Physic and Infrastructure Affairs. They were also gave a development planning documents as secondary data to support the findings of this study. This data study was analyst by Interactive Model by Miles and Huberman (2013:14).

\section{Results and Discussion}

This study found that to achieve the fourth Mission of current Medium Term of Development Planning (MTDP), then form Surabaya GCMP. It is a combination between livable city and sustainable city or it is known as a sustainable development. The concept of livable city is the city which described as having a comfortable atmosphere as residence or place to make some activities viewed from various aspects, both physical (urban facilities, infrastructures, land use, etc.) and non-physical (social relations, economic activities, etc.) While the concept of sustainable city is the development to fulfill the present need without harm the next generation to fulfill their own needs or called sustainable development.

Surabaya GCMP consist 8 elements, there are: (1) Green planning and design is to set the Regional Spatial Plan (RSP) of Surabaya City to have $30 \%$ green open 
space of the total area, which is $20 \%$ provided by the public and $10 \%$ provided by private; (2) Green open space is the city will expand and optimize green open space; (3) By Green building, the city determinate infrastructures and green buildings development policy, and organize Green Building Award;(4) In Green transport, the city plan for Mass Rapid Transport in the form of monorail and tram, and provide a network of non-motor vehicle; (5) For Green society the government will develop facilitator and environmental cadres, organize Free Waste event, and Surabaya Green and Clean; (6) In Green waste, the government will built recycling centers and composting houses, develop Benowo landfill by using trash-to-energy technology; (7) Green water will be realized by develop a clean and drinking water network, wastewater network and urban domestic garbage management; and (8) Green energy will be conducted by developing an alternative energy like solar cell in public infrastructure, construction of cogeneration power source in the industry.

\section{Environmental scanning}

Environmental scanning process conducted by Surabaya City Government to achieve GCMP is in accordance as perceived by Wheelen et al (2015:15), Parnell (2014:14), Coulter (2013:5), Fard (2011), and Dess et al (2010:13-16) which express that environmental scanning is the process is of monitoring, evaluating, and disseminating an information from external and internal environments to identify some factors that will assist the analysis in deciding the strategic formulation.

According to MTDP 2010-2015 of Surabaya City Government, there are factors in external and internal environment of Surabaya City Government that will influence strategy formulation to achieve Surabaya GCMP. The external environment consist of opportunities and threats in Surabaya City Government organizations, and the internal environment consist of strength and weakness of Surabaya City Government.

\section{External environment}

\section{Opportunities}

a. Entering 2010, Indonesia and other countries in ASEAN entering the agreement's implementation of the ASEAN-China Free Trade Agreement (ACFTA). So that every city in Indonesia, especially Surabaya is expected to prepare the city in terms of facilities and infrastructure, as well as environmental conditions.

b. Surabaya city has a strategic position both in the regional and national scale as a service center for trade and services in East Java, and as a center for the development of the eastern part of Indonesia. So the facilities and environmental conditions need to be considered and develop;

c. People of Surabaya tend to utilize the open green space for various purposes with other functions;

d. People of Surabaya always actively participated in various development programs, especially in terms of environmental development programs.

\section{Threats}

a. There is fact that Indonesia's competitiveness continues to decline. So that Surabaya has to create a policy framework that is capable of creating a conducive economic climate;

b. The city dynamics and activities are very high to trigger the development of the city very quickly, so it need an integrated control to be more focused in the development;

c. There are big companies from national and international levels come into the city, it become a challenge for sustainable development in the city of Surabaya.

\section{Internal environment}

\section{Strength}

a. There are supporting document such as, national policy, act, MTDP, local regulation, mayor regulation, and rule of law that will support the policy at city level;

b. There is a clear Vision and Mission of Surabaya City that support green development;

c. There is a clear structure in Surabaya City Government, so that the implementation of responsibility can run effectively.

\section{Weakness}

a. A high level of urbanization is accompanied by the increase of people each year.

However, the environmental scanning conducted by BAPPEKO of Surabaya is not only based on SWOT analysis. Besides using SWOT analysis, it was found that Surabaya City Government also do netting to the people aspiration via E-Musrenbang. The utilization of IT in E-Musrenbang make the community more actively to express their opinions to the development in Surabaya City. With it also, the government was able to easily determine the appropriate development program in accordance with the needs of the community. 


\section{Strategy formulation}

The strategy formulation in strategic management process of Surabaya City Government to achieve Surabaya GCMP is the process of investigation, analysis, and decision making that provides Surabaya City Government with the criteria to achieve the goal. It includes defining mission, specifying achievable objectives, crafting strategies and setting policy guidelines. It purpose to develop a long-range planning that will assist Surabaya City Government in achieving Surabaya GCMP.

The presence of BAPPEKO of Surabaya is as a coordinator of development planning and carrying out the task of coordinating the preparation, control and evaluation of the implementation of local development plans. BAPPEKO can be described as a strategist. Because of what they have done is inline what expressed by White (2004:7) that every strategy must be made by strategist. BAPPEKO of Surabaya is one of who has the responsibility to takes the successful formulation and implementation. However, BAPPEKO of Surabaya is also help by another government unit to do it.

The utilization of Information and Technology (IT) in E-Musrenbang by BAPPEKO of Surabaya since 2009 , was successfully involve the society in lower level to participate and provide an input on strategy formulation of BAPPEKO of Surabaya. BAPPEKO of Surabaya can easily design an appropriate policy formulation and in accordance with the needs of the community. BAPPEKO of Surabaya also successfully accommodate and facilitate transparently throughout the aspirations of the people.

\section{Mission}

The reason of the existence of Surabaya GCMP derived from the fourth mission of MTDP chapter V about Vision and Mission 2010-2015 of Surabaya City (Rismaharini, 2012:7) which says "Menjadikan Kota Surabaya semakin layak-huni melalui pembangunan infrastruktur fisik dan sosial secara merata yang BERWAWASAN LINGKUNGAN" (making the Surabaya City increasingly livable of physical and social infrastructure through GREEN DEVELOPMENT).

\section{Objectives}

The objectives in strategy formulation of Surabaya City Government to achieve Surabaya GCMP is what results to accomplish by Surabaya City Government. According to MTDP chapter V about Vision and Mission 2010-2015 of Surabaya City Government (Rismaharini, 2012:9), the objectives of Surabaya
GCMP is the eight element of Surabaya City Master Plan which is the translation from the fourth mission of MTDP 2010-2015 of Surabaya City:

1) Develop a management system, synergy among the network and the establishment of urban infrastructure;

2) Improving the quality and quantity of green open space and urban forest.

3) Improving the implementation of an integrated spatial planning;

4) Increase the actualization of the local culture to support the development of the object of tourist attraction environmentally sound.

\section{Strategies}

Strategies in strategy formulation of Surabaya City Government to achieve Surabaya GCMP is plan to achieve the mission and objectives of Surabaya GCMP. According to MTDP chapter VI about Strategy and Policy Direction (Rismaharini, 2012:7), strategies to achieve the objectives of are:

a. Develop a management system, synergy among the network and the establishment of urban infrastructure;

1) Improve the municipal utility systems and networks;

2) Improve the provision of facilities and infrastructure for disaster management;

3) Improve the provision of facilities and infrastructure for urban drainage systems;

4) Develop an integrated transportation systems and sustainable urban-based mass transit;

5) Increase the accessibility between regions by increasing the capacity, performance, performance improvement of roads and bridges;

b. Improving the quality and quantity of green open space and urban forest.

1) Implementing the spatial planning with participative approach.

c. Improving the implementation of an integrated spatial planning;

1) Improving the hygiene and develop an efforts to protecting and controlling environment impacts.

2) Applying the principles of ecologically sustainable development in the development of the city;

d. Increase the actualization of the local culture to support the development of the object of tourist attraction environmentally sound.

1) Developing a cultural wisdom with character and personality;

2) Improving the management of partnership and cooperation in the development of tourist attraction object. 
In the section of Mission, Objectives, Strategies and Policies, there is a mutually binding relationship between one with another. All of it is related one to another. Mission created by the Vision and Mission of MTDP 2010-2015 of Surabaya City, this is which become a forerunner of formation of Surabaya GCMP. From Mission then created an objectives or results to accomplish by Surabaya City Government. To accomplish the objectives then formulate plan to achieve it, it call strategies.

\section{Policies}

To make sure that the strategies has a broad guidelines for decision making then formulate the policies. Policies in strategy formulation of Surabaya City Government to achieve Surabaya GCMP is a broad guidelines for decision making according to the strategies. According to MTDP chapter VI Strategy and Policy Direction (Rismaharini, 2012:7-8), policies used to make decision making. It also consist of sequence of steps as rules of the implementation in achieving Surabaya GCMP. It aims to maintain the sustainability of development. In implementing Surabaya GCMP is also based on it. It will help the implementation keep on the track to achieve the objectives.

\section{Strategy implementation}

The strategy implementation in strategic management process of Surabaya City Government to achieve Surabaya GCMP is a process that strategies and policies are put into action through the development of programs and budgets.

\section{Programs}

In order to achieve the eight element of Surabaya GCMP, through a strategy which has been mentioned in before, then drafted programs as a guideline for Local Working Unit and agencies in formulating their policies and programs in accordance with their respective functions. As in the case of Surabaya GCMP, the related programs adapted to the existing strategies, as follows:

1. Develop a management system, synergy among the network and the establishment of urban infrastructure;

a. Management and Construction of Roads and Bridges Program;

b. Flood Control Program;

c. Development of Urban Clean Water Network Program;

d. Housing and Settlement Program;

e. Prevention and Management of Fire Program; f. Urban Utilities Program;

g. Transport System Development Program;

h. Green Open Space Management Program.

2. Improving the quality and quantity of green open space and urban forest;

a. Spatial Planning Program

3. Improving the implementation of an integrated spatial planning;

a. City Cleanliness Management Program;

b. Control of Pollution and Environmental Destruction Program;

4. Increase the actualization of the local culture to support the development of the object of tourist attraction environmentally sound.

a. Cultural Diversity Management Program;

b. Tourism Destionation Development Program.

\section{Budgets}

Budgets is a cost of the programs in Surabaya GCMP. According to Mrs. Arum, to achieve Surabaya GCMP, the budget is entirely come from Surabaya Local Government Budget. According to MTDP 20102015 of Surabaya City chapter III about Local Financial Management (Rismaharini, 2012:7), the estimation of local revenue to fund Surabaya GCMP activities are come from: Local Own-source Revenue, Fiscal balance (transfers from the central government to regions), and Other Lawful Local Revenue.

Seeing what was done by the Surabaya City Government in managing their regions, especially in achieving Surabaya GCMP, it is a good government. Local government budget comes from the community, run by the government and the allocation of funds is perceived by the public.

\section{Control and evaluation}

The evaluation and control in strategic management process of Surabaya City Government to achieve Surabaya GCMP is a process in which Surabaya City Government activities and performance results are monitored so that actual performance can be compared with desired performance.

However, it is also, people who have proposed proposal via E-Musrenbang can perform control at all times related to measures the policy taken by the government. Even in the implementation of Surabaya GCMP program in the field, the community can monitor even evaluation through Surabaya Media Center (ESapawarga, Surabaya.go.id, Twitter, Facebook, Email, and Call Center/ SMS) provided by Surabaya City Government).

The involvement of other stakeholders in the process of control and evaluation through Surabaya 
Media Center is one of the elements to achieve the objectives effectively and efficiently. It also makes the Surabaya City Government to be more responsive to complaints and problems faced by the community, and even created a solution as expected by the public. According to Mclnerney \& Barrows (2002) government responsiveness to the interest of stakeholders and society as a whole are fundamental and extremely critical to service delivery and performance.

What was done by Surabaya City Government in achieving GCMP can be draw like figure 1 below

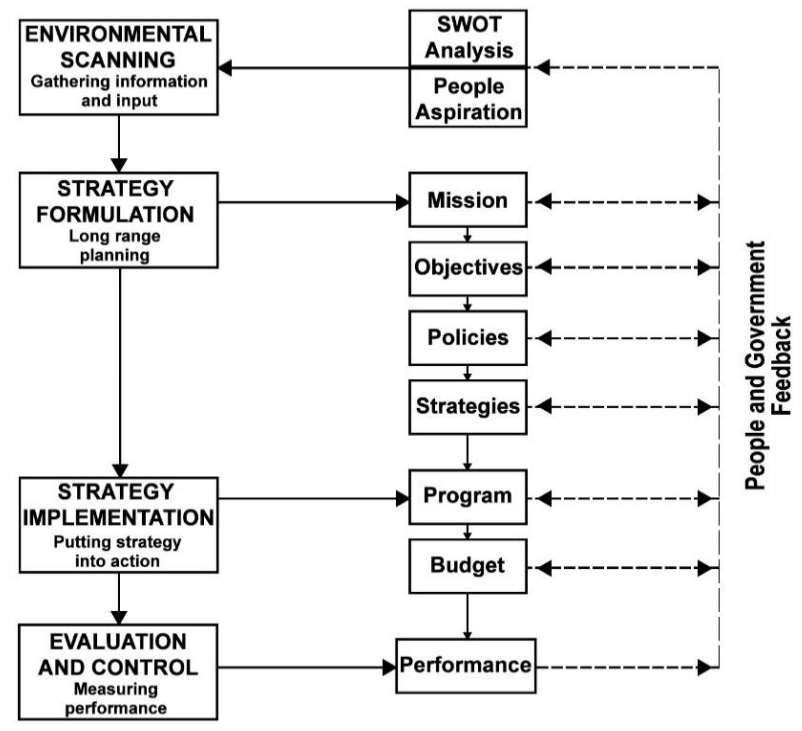

Figure 1 Strategic Management Process of Surabaya City Government in achieving GCMP

\section{Conclusion}

This study conclude that the strategic management process of Surabaya City Government in achieving GCMP done by an active community participation. This is because of the utilization of IT and social media as a liaison between the government and society, and allowed the government to create an appropriate program which is supported by the society. What was done by Surabaya City Government illustrates that the utilization of IT and social media at this time will have an impact on the active community participation in strategic management process, especially in the various government programs.

However, this study is still need to be improved by another research. The writer suggest the further study to conduct a research to found a supporting factors and obstacles in strategic management process. The writer also suggest to look on the effectiveness of policies and programs created by the government based on EMusrenbang to the community.

\section{References}

Aditya, B. R. (2016). An analysis of strategic management process of Surabaya City Government to achieve green city master plan (Unpublished master's thesis). Burapha University, Chonburi, Thailand.

Backoff, R., Whechsler, B., \& Crew, R. E. Jr. (1993). Public administration quarterly. The challenge of strategic management in local government, 17(2), 127-144. Retrieved from http://search.proquest.com/docview/226959551?a ccountid $=44783$

Bainey, K. R. (2004). Integrated IT project management: a model-centric approach. London, UK: Artech House.

Beatley, T. (2012). Introduction: Why Study European Cities?. In Green Cities of Europe (pp. 1-28). Island Press/Center for Resource Economics.

Brüel, M. (2012). Copenhagen, Denmark: Green City amid the Finger Metropolis. In Green Cities of Europe (pp. 83-108). Island Press/ Center for Resource Economics.

Bryson, J. M. (1988). A strategic planning process for public and non-profit organizations. Long range planning, 21(1), 73-81.

Coulter, M. (2013). Strategic management in action (6th ed.). United State: Pearson Education.

Çınar, O., \& Karcıoğlu, F. (2013). The Relationship between Strategic Management, Institutionalization and Human Resource Management: A Survey Study with Family Businesses Located in the Northeast Anatolia Sub Economic Region of Turkey. Procedia-Social and Behavioral Sciences, 99, 835-842.

David, F. R. (2007). Strategic management: Concept and cases (11th ed.). United States: Pearson Prentice Hall.

Dess, G. G., Lumpkin, G. T., \& Eisner, A. B. (2010). Strategic management: Creating competitive advantages (5th ed.). Singapore: McGRAWHILL.

DPUCKTR. (2013). Green Building Awareness Award. Retrieved from http://dcktr.surabaya.go.id/cktrweb/index.php?opt ion $=$ com_content \&view=article\&id=91:greenbuilding-awareness award \&catid $=80 \&$ Itemid $=294$

Environmental Board of Surabaya City Government. (2009). Pencemaran Air, Udara dan Tanah. Retrieved April 9, 2016, from http://www.lh.surabaya.go.id/weblh/?c=main\&m =pencemaran

Fard, H. D., Moshabbaki, A., Abbasi, T., \& Hassanpoor, A. (2011). Strategic management in the public 
sector: reflections on its applicability to Iranian public organizations. Public Organization Review, 11(4), 385-406. doi: 10.1007/s11115010-0140-5

Gecíková, I., \& Papcunová, V. (2014). Using of strategic management tools in conditions of local self-government in Slovakia. Procedia-Social and Behavioral Sciences, 110, 969-978.

Indonesia, R. (2004). Indonesian Act number 32 of 2004 on Local Government. Retrieved from Ministry of Law and Human Rights of the Republic of Indonesia: http://peraturan.go.id/uu/nomor-32tahun-2004.html

Indonesia, R. (2009). Indonesian Act number 32 of 2009 on Protection and Environmental Management. Retrieved from Ministry of Law and Human Rights of the Republic of Indonesia: http://peraturan.go.id/uu/nomor-32-tahun 2009.html

Kloot, L., \& Martin, J. (2000). Strategic performance management: A balanced approach to performance management issues in local government. Management Accounting Research, 11(2), 231-251. Retrieved from http://dx.doi.org/10.1006/mare.2000.0130

Levicki, C. (1999). The interactive strategy workout: Analyze and develop the fitness of your business (2nd ed.). Great Britain: Financial Times Prentice Hall.

Lynn, L. E. (2006). Public management: Old and new. United States: Routledge.

McInerney, R. \& Barrows, D. (2002). Management tools for creating government responsiveness: The liquor control board of Ontario as a context for creating change. The innovation journal-The Public Sector Innovation Journal, 7(3), article 10. Retrieved-from:

http://www.innovation.cc/volumes-issues/vol7iss3_leadership.htm

Miles, M. B., Huberman, A. M., \& Saldana, J. (2013). Qualitative data analysis: A methods sourcebook. SAGE Publications, Incorporated.

Murota, Y., \& Ito, K. (1996). Global warming and developing countries: The possibility of a solution by accelerating development. Energy Policy, 24(12), 1061-1077.

Nutt, P. C., \& Backoff, R. W. (1993). Transforming public organization with strategic management and strategic leadership. Journal of Management, 19(2),299-347.doi:10.1177/014920639301900206

Nuh, M. (2014). The strategic management of good governance in local government: a comparative study between Yogyakarta city, Indonesia and Pattaya city, Thailand. Doctoral' thesis, Political
Science in Strategy and Security, Faculty of Political Science and Law, Burapha University.

Parnell, J. A. (2014). Strategic management: Theory and practice (4th ed.). Los Angeles: SAGE.

Ring, P. S., \& Perry, J. L. (1985). Strategic management in public and private organizations: Implications of distinctive context and constraints. Academy of management review, 10(2), 276-286. doi:10.5465/AMR.1985.4278197

Rismaharini, T. (2012). Surabaya City Regional Medium Term Development Plan. Surabaya: Surabaya City Government.

Sani, R.D. (2014). Adipura Rated and Ranked of 2013. Retrieved from Ministry of Environment of the Republic of Indonesia:

http://www.menlh.go.id/wp-content/uploads/dow nloads/2014/09/Nilai-dan-Peringkat-Adipura2013.pdf

Surabaya. (2015). Profile of Surabaya City. Retrieved October-11-2015,from http://www.surabaya.go.id

/berita/8224-profil-of-surabaya

Sutawijaya, I. G. (2010). Design of Sanitary Landfill in the Extended Area of Benowo Final Disposal Site. Undergraduate's theses, Institut Technology Sepuluh November, Surabaya. Indonesia.

Widigdo, W., \& Canadarma, I. K. (2010). Surabaya sebagai kota taman atau green city. Retrieved from Universitas Kristen Petra website: http://repository.petra.ac.id/15196/1/Surabaya_me njadi_Kota_Taman_atau.pdf

Wikantiyoso, R., \& Tutuko, P. (2013). Planning Review-Green City Design Approach for Global Warming Anticipatory. International Review for Spatial Planning and Sustainable Development, 1(3), 4-18.

Wheelen, T. L., Hunger, J. D., Hoffman, A. N., \& Bamfoed, C. E. (2015). Strategic management and business policy: Globalization, innovation, and sustainability (14th ed.). United States: Pearson Education.

White, C. (2004). Strategic management. China: Palgrave Macmillan. 